\title{
ISTORIJA
}

\section{STEIGIAMOJO SEIMO DARBAI ŠVIETIMO SRITYJE: LŪKESČIAI IR PROBLEMOS}

\author{
Dr. Audroné VeilentienĖ
}

Kauno technologijos universitetas

Kaunas University of Technology

K. Donelaičio g. 73, LT-44029 Kaunas

El.paštas audrone.veilentiene@ktu.lt

\section{Santrauka}

Straipsnyje analizuojami Steigiamojo Seimo darbai švietimo srityje. Svarbiausi Steigiamojo Seimo priimti istatymai šioje srityje buvo Lietuvos universiteto statutas ir Pradžios mokyklu įstatymas. Be to, Lietuvos Respublikos Konstitucijoje buvo įteisintas privalomas pradinis išsilavinimas ir privalomas tikybos mokymas. Straipsnyje atskleidžiamos frakciju ir kai kuriu Seimo nariu ideologines nuostatos švietimo klausimais. Valdantysis Krikščioniu demokratų blokas siekè įtvirtinti savo ideologines nuostatas, kurioms pritare dauguma Lietuvos gyventoju, Liaudininku ir Socialdemokratu frakciju priešiškas nusistatymas dèl religijos trukdè suprasti Krikščioniu demokratų bloko siekius ir eiti ị kompromisus.

Reikšminiai žodžiai: Seimas; frakcija; universitetas; statutas; mokykla; švietimas; ịstatymo projektas.

\section{Ivadas}

Steigiamajame Seime daugumą turejusị Krikščionių demokratų bloką ir Lietuvos socialistų liaudininkų demokratų partijos ir Lietuvos valstiečiu sąjungos bloką vienijo artimas požiūris ị Lietuvai iškilusias 
politines ir žemės reformos problemas, tačiau juos skyrè didžiuliai ideologiniai nesutarimai, ypač dèl Bažnyčios ir dvasininkijos statuso šalyje, tikybos dėstymo mokykloje. Sudarydami koaliciją ir formuodami Ministrų kabinetą krikščionys demokratai padarẻ kairiesiems nuolaidų: sutiko pripažinti civilinę gimimų, mirimų ir vedybų registraciją, neskelbti né vienos tikybos valstybine, neversti mokyklose lankyti tikybos pamokas tų mokinių, kurių tėvai to nenorejjo, ir kita. ${ }^{1}$ Tikejjimo ir Bažnyčios klausimai buvo aplenkti ir Laikinojoje Konstitucijoje. Kol Lietuvos nepriklausomybei grèsė pavojus, prieštaravimus tarp koalicijos partnerių buvo bandoma užglaistyti, tačiau praejjus išoriniam pavojui priešprieša labai sustiprejo. $1921 \mathrm{~m}$. rudenị, pradejus Seime svarstyti Konstitucijos, Žemès reformos, Universiteto statuto ir Pradinių mokyklų įstatymų projektus, koalicija pradejo griūti. Liaudininkai manè, kad Bažnyčia turi būti atskirta nuo valstybès, dvasininkams atlyginimas neturi būti mokamas iš valstybès iždo, kad nereikia bažnyčioms ir vienuolynams grąžinti XIX a. caro valdžios nusavintų žemių, kad Lietuvos universitetui nereikalingas Teologijos fakultetas, o tikybos pamokos mokyklose neturi būti privalomos. Jų pozicijai pritarè ir Lietuvos socialdemokratų partijos frakcija Seime, tačiau daugumą Seime turejję krikščionys demokratai negalejo nepaisyti 90 procentų šalies gyventojų nuomonès. Visus su švietimu susijusius projektus, kuriuos parengdavo Švietimo ministerija, pirmiausia apsvarstydavo Steigiamojo Seimo Švietimo komisija, kurios pirmininkas buvo Krikščionių demokratų bloko atstovas Kazimieras Jokantas, nariai - krikščionys demokratai kunigas Antanas Šmulkštys ir Magdalena Galdikiené, Valstiečių liaudininkų bloko atstovai - Antanas Tamošaitis ir Kazys Kupčiūnas, Socialdemokratų frakcijos atstovas Antanas Purènas ir Žydų frakcijos atstovas Maksas Soloveičikas. Komisija gerokai pakeisdavo gautą įstatymo projektą ir Seimo plenumo posėďiuose kildavo

Truska, L. Steigiamasis Seimas ir jo vieta naujujų laikų Lietuvos istorijoje. Lietuvos steigiamojo seimo (1920-1922 metu) nariu biografinis žodynas. Vilnius: Vilniaus pedagoginio universiteto leidykla, 2006, p. 37. 
nemažai diskusijų. Svarbiausi Steigiamojo Seimo priimti įstatymai švietimo srityje yra Lietuvos universiteto statutas ir Pradžios mokyklų ìstatymas. Taip pat Steigiamasis Seimas prièmė Žemesniųjų žemės ūkio mokyklų ịstatymą ir Namų, ūkio ir ruošos mokyklos ịstatymą ${ }^{2}$, svarstè, tačiau nespejjo priimti Susisiekimo technikos mokyklos istatymo, Švietimo ministerijos muzikos mokyklos įstatymo ir Bendrojo lavinimo mokyklų ịstatymo. 1922 m. rugpjūčio 1 d. priimtoje Konstitucijoje, IX skyriuje, buvo įteisintas privalomas nemokamas pradžios mokslas visiems 7-14 metų vaikams. Šio straipsnio tyrimo objektas - svarbiausių su švietimu susijusių ịstatymų projektų bei Konstitucijos straipsnių svarstymas ir priemimas Steigiamajame Seime, frakcijų ir atskirų Seimo narių požiūris ị švietimą.

Istoriografija: Steigiamojo Seimo darbai švietimo srityje nei tarpukariu, nei sovietų okupacijos metais nebuvo plačiau analizuojami. Apie pradines mokyklas tarpukariu rašė Jonas Vokietaitis ${ }^{3}$ ir Petras Papečkys ${ }^{4}$, tačiau jų straipsniuose ịstatymo prièmimas plačiau nebuvo analizuojamas. Sovietų okupacijos metais švietimo politiką parlamentiniu laikotarpiu istorikai vertino neigiamai, vadino ją „antiliaudine“ ir „antinacionaline“ klerikalų politika ${ }^{5}$.

Lietuvai atgavus nepriklausomybę, atsirado palankios galimybès Lietuvos istorijos, o kartu ir švietimo istorijos tyrinejjimams. Bendrojo lavinimo vidurinès mokyklos teisinę kūrybą savo monografijoje

1922 m. birželio 16 d., I sesijos 213 posèdis. Steigiamojo Seimo darbai. Kaunas, 1920-1922; 1922 m. spalio 6 d., I sesijos 257 posėdis. Steigiamojo Seimo darbai. Kaunas, 1920-1922.

3 Vokietaitis, J. Pradžios mokslo plitimo 10 metų (1918-1928) apžvalga. Pirmasis Nepriklausomos Lietuvos dešimtmetis, 1918-1928. Kaunas: Šviesa, 1990, p. 308313.

4 Papečkys, P. Mūsų laimèjimai švietimo dirvoje. Lietuva 1918-1938. Kaunas: Šviesa, 1990, p. 267-289.

5 Gricevičiūtè, J. Antiliaudinè krikščioniu demokratu partijos politika Lietuvoje (1920-1926 m.). Vilnius, 1953; Jurkūnas, J.; Levinauskas, D. Antinacionaliné lietuviškujų klerikalu politika. Vilnius, 1955. 
analizavo Saulius Kaubrys ${ }^{6}$, kultūrinès autonomijos santyki su katalikiško švietimo sistema nagrinėjo Dangiras Mačiulis ${ }^{7}$, Universiteto statutų raidą tarpukariu aukštojo mokslo istorijai skirtoje monografijoje analizavo Česlovas Mančinskas ${ }^{8}$.

Straipsnio tikslas: išanalizuoti Steigiamojo Seimo darbus švietimo srityje, palyginti partijų nuostatas švietimo klausimais.

Chronologinès ribos - 1920-1922 metai.

Tyrimo metodai: aprašomasis, analizès ir lyginamasis.

\section{Nesutarimai dèl Lietuvos universiteto statuto}

Lietuvos universiteto statuto projektas ị Seimą pateko $1921 \mathrm{~m}$. rugpjūčio 30 d. ir buvo perduotas Švietimo komisijai, tačiau tik gruodžio 7 d. pradètas svarstyti Seimo plenume ${ }^{9}$. Referentas K. Jokantas paaiškino, kad Universitetas Lietuvoje kuriamas pavèluotai dèl lèšu ir patalpų trūkumo. Tikètasi, kad pagerèjus Lietuvos tarptautinei padéčiai atsiras daugiau léšų mokslo ir kultūros ịstaigoms, tačiau taip neatsitiko. K. Jokantas pareiškè, kad daugiau delsti negalima, nes Universiteto neturèjimas neigiamai atsiliepia ir Lietuvos užsienio politikai, juk naujai susikūrusios valstybès yra vertinamos ir pagal tai, ar turi aukštąją mokyklą ${ }^{10}$. Referentas tikejosi, kad Seimas visais trim skaitymais Universiteto statutą priims iki šv. Kalèdų, o nuo Naujųjų metų bus galima atidaryti Universitetą.

6 Kaubrys, S. Lietuvos mokykla 1918-1939 m.: galios gimtis. Vilnius: VšI „Statistikos tyrimai", 2000.

7 Mačiulis, D. Kultūrinès autonomijos idejja ir katalikiško švietimo sistema tarpukario Lietuvoje (1918-1940 m.). Lietuviu kataliku mokslo akademijos metraštis. Vilnius, 2011, t. 35.

8 Mančinskas, Č. Aukštasis mokslas Lietuvoje 1918-1940 metais. Vilnius, 1996.

91921 m. gruodžio 7 d., I sesijos 147 posèdis. Steigiamojo Seimo darbai. Kaunas, 1920-1922.

10 Ten pat. 
Socialdemokratų atstovas prof. Vincas Čepinskis paaiškino, kad Universiteto statutas buvo parengtas Aukštụjų kursų iniciatyva dar 1920 m. rudenị ir ịteiktas Švietimo ministerijai, o iš ministerijos ị Seimą pateko tik $1921 \mathrm{~m}$. rudenị. Profesorius kritikavo statutą, kad, viena vertus, suteikiama plati autonomija ne tik Universitetui, bet ir atskiriems fakultetams, antra vertus, - autonomija varžoma, nes Teologijos fakultete profesoriai skiriami tik su episkopato sutikimu. Jis neprieštaravo, kad Universitete būtų Teologijos fakultetas, tačiau nenorejo, kad Krikščioniškos filosofijos ir Pedagogikos skyriai būtų kitame - Filosofijos (arba Humanitarinių mokslų) fakultete. Jo nuomone, taip krikščionys demokratai nori „paimti savo globon“ socialinius mokslus, o paskui ir visą Universitetą paversti katalikišku.

Krikščionių demokratų atstovas kunigas A. Šmulkštys paaiškino, kad gavusi statuto projektą Seimo Švietimo komisija svarste ji komisijos posėdžiuose 3 mėnesius 2 kartus per savaitę, nes norejo gerai ji parengti. Pasak jo, krikščionių demokratų konferencija, vykusi rugsejjo 15 d., norèjo, kad kuo greičiau būtų ìsteigtas Universitetas, tačiau visi numatyti fakultetai, o ne tik dalis jų. Taip pat jis pasisakè už Teologijos fakulteto îsteigimą ir Krikščionių filosofijos bei Pedagogikos katedras Humanitariniame fakultete. Jo nuomone, fakultetams taip pat turi būti suteikiama autonomija. Seimas vienbalsiai nusprendè, kad Universiteto statuto projektas tinkamas svarstyti Seimo plenume.

Gruodžio 14 d. Steigiamasis Seimas svarstė Universiteto statutą antruoju skaitymu ${ }^{11}$. Daugumos balsais A. Šmulkščio pataisa Humanitarinị fakultetą pavadinti Filosofijos fakultetu buvo priimta. Liaudininkas A. Tamošaitis priekaištavo, kad kuriamas Katalikų universitetas, nes tą rodo statute įrašyta Krikščionių filosofijos ir pedagogikos katedra. Tuomet A. Šmulkštys pasiūle šalia ịkurti Filosofijos ir pedagogikos katedrą. Jo siūlymui vèl pritarè Seimo dauguma. Taip pat neprieštarauta ir jo minčiai, kad profesorius skirtų ne Švietimo ministerija, o

${ }_{11} 1922$ m. gruodžio 14 d., I sesijos 150 posėdis. Steigiamojo Seimo darbai. Kaunas, 1920-1922. 
Prezidentas. V. Čepinskis siūlè, kad daktaro laipsnis būtų pripažįstamas paprasčiau, A. Šmulkščio nuomone, tam reikalingi tam tikri egzaminai.

Didžiausių nesutarimų sukèlè noras ịkurti Teologijos fakultetą, bet taip pat buvo diskutuojama ir dèl Agronomijos, arba Žemès ūkio, instituto steigimo. Seimo narys agronomas Jonas Kriščiūnas siūlè institutą ¡kurti prie Universiteto Gamtos fakulteto, o ne atskirai Dotnuvoje, kaip norejjo Žemès ūkio ministerija. Jo nuomone, geriau turèti vieną stiprią aukštąją mokyklą negu kelias silpnas, nes nèra tiek dėstytojų, o iš kitų valstybių geri specialistai ị neturtingą Lietuvą nevažiuos ${ }^{12}$.

$1922 \mathrm{~m}$. sausio $13 \mathrm{~d}$. vykusiame Seimo posèdyje Socialistų liaudininkų ir Valstiečių sąungos blokas atšaukè Ministrą Pirmininką Kazị Grinių iš Vyriausybės, nenorèdamas „nešti atsakomybės už krikščionių demokratų daugumos grynai partinę ir klerikalinę politiką"13. Antanas Smetona straipsnyje „Dèl naujojo ministerių kabineto“ rašè, kad liaudininkai, nutraukdami koaliciją, nori visą atsakomybę suversti ant Seimo daugumos pečių, o patys ruošiasi rinkimams ${ }^{14}$. Jo nuomone, vengdami atsakomybės už nevykusią užsienio politiką ir opesnius vidaus politikos klausimus, jie prisidengia kritikuodami švietimo ir tikybos reikalus.

Vasario $7 \mathrm{~d}$. Universiteto statutas buvo svarstomas Seimo posėdyje trečiuoju skaitymu. Socialdemokratų frakcijos atstovas V. Čepinskis perskaite savo frakcijos pareiškimą, kad ji nesutinka su Universiteto statutu, priimtu Seime antruoju skaitymu, nes jo pataisos pažeidžia Universiteto autonomiją. Frakcija, pripažindama Lietuvos katalikiškajai visuomenei teisę turèti Universitete Teologijos fakultetą, nesutinka, kad šio fakulteto katedros būtų steigiamos Filosofijos fakultete.

12 Kriščiūnas, J. Ar yra reikalo steigti atskiras Agronomijos institutas? Lietuva. 1922, vasario 8 (Nr. 32), p. 2.

131922 m. sausio 13 d., I sesijos 158 posėdis. Steigiamojo Seimo darbai. Kaunas, 1920-1922.

14 A. Sm. [A. Smetona]. Dèl naujojo ministerių kabineto. Tèvynès balsas. 1922, vasario 4-5 (Nr. 12), p. 1. 
Taip pat frakcija mano, kad profesorius Universitetui gali skirti Švietimo ministerija, o ne Prezidentas. Anot socialdemokratu, statute turi būti įrašyti tik fakultetai ir skyriai, o katedrų skaičių pasirinkti palikta pačiam Universitetui. Švietimo ministerijai reikia suteikti teisę skirti personalą, kol Universitete susiformuos fakultetų tarybos. Jų manymu, fakulteto autonomijos esmè yra ta, kad vienas fakultetas neturi teisés kitam fakultetui primesti savo nuomonès. Kalbos pabaigoje V. Čepinskis pareiškè, kad frakcija nedalyvaus tolesnèse diskusijose, žinodama, kad i jos nuomonę nebus atsižvelgta, todèl palieka Universiteto statuto klausimą Krikščionių demokratų bloko atsakomybei ${ }^{15}$.

A. Šmulkščiui padèkojus socialdemokratams už mandagumą, kad jie sutiko palikti Teologijos fakultetą, Socialdemokratų frakcija triukšmingai atsistojo ir išèjo iš Seimo salès. Liaudininkų atstovas Vladas Lašas kaltino, kad statutas vienpusiškas, pažeidžiama Universiteto autonomija, kad daugiausia katedrų turi Teologijos fakultetas, o profesorius jam parinks episkopatas. Krikščionių demokratų blokui atmetus kairiųjų frakcijų pataisas, Socialistų liaudininkų frakcija taip pat išejo iš Seimo posėdžio. Nelikus kvorumo, Seimo posėdis buvo nutrauktas. Universiteto statuto svarstymas buvo tęsiamas kitos dienos posėdyje, tačiau kairiosioms frakcijoms išèjus iš salès Seimo Pirmininkas Aleksandras Stulginskis pasiūle šį klausimą atidèti kitam posėdžiui ${ }^{16}$.

Naująji Ministrų kabinetą suformavo Ernestas Galvanauskas, švietimo ministru tapo Aukštųjų kursų lektorius Petras Juodakis. Siekdamas nuraminti Steigiamajame Seime ir visuomenèje kilusias aistras dèl Universiteto naujasis Ministrų kabinetas vasario $13 \mathrm{~d}$. nutarė atidaryti Universitetą, tai yra nelaukti statuto patvirtinimo Seime, bet pasiremti 1918 m. gruodžio 5 d. Lietuvos Tarybos išleistu įstatymu ir Vilniaus

${ }_{15} 1922$ m. vasario 7 d., I sesijos 168 posėdis. Steigiamojo Seimo darbai. Kaunas, $1920-1922$.

161922 m. vasario 8 d., I sesijos 169 posėdis. Steigiamojo Seimo darbai. Kaunas, 1920-1922. 
universiteto statutu ${ }^{17}$. $1922 \mathrm{~m}$. vasario $16 \mathrm{~d}$. Lietuvos universitetas buvo iškilmingai atidarytas.

Kovo $22 \mathrm{~d}$. Universiteto statutas buvo pradètas svarstyti trečiuoju skaitymu nuo pirmojo paragrafo. Numatyti tokie Universiteto fakultetai: Teologijos-filosofijos, Humanitarinių mokslų, Teisių, Matematikos-gamtos, Medicinos ir Technikos. Tačiau referentas K. Jokantas Švietimo komisijos vardu siūle Teologijos-filosofijos fakulteto pavadinimą pakeisti ị Katalikų fakultetą ${ }^{18}$. Tam griežtai prieštaravo Socialdemokratų frakcijos narys V. Čepinskis, jis teigè, kad pasaulyje nèra nè vieno universiteto, turinčio Katalikų fakultetą. Jis įžiūrèjo krikščionių demokratų slaptą norą padaryti visą Universitetą katalikišką ir pareiškè, kad Socialdemokratų frakcija su tuo nesutinka ir tokio statuto prièmimo procese nedalyvaus. Prof. V. Čepinskis siūlè fakultetą pavadinti Teologijos fakultetu, nes teologija yra labai platus mokslas. Mykolas Sleževičius Lietuvos socialistų liaudininkų demokratų partijos ir Lietuvos valstiečių sąungos frakcijų vardu taip pat pareišké, kad pavadinimas „Katalikų fakultetas“ yra nepriimtinas ir neleistinas, nes negalima iš mokslo įstaigos daryti „tikybinę ịstaigą“. Kunigas Juozas Vailokaitis neslèpé, kad frakcijos susitarè, jog Universitete bus kuriamas vienas Teologijos-filosofijos fakultetas, o ne du, kaip buvo norima anksčiau. Jo nuomone, pavadinimas „Katalikų fakultetas“ turi platesnę prasmę, apima visus jam reikalingus mokslus ir leidžia suprasti, kad jame galès studijuoti ne tik kunigai, bet ir pasauliečiai, tarp jų - ir moterys, tačiau šis fakultetas bus tvarkomas pagal Bažnyčios kanonų teisę. Teologijos-filosofijos fakulteto pavadinimą taip pat parèmé švietimo ministras P. Juodakis.

Vis dèlto 43 balsais prieš 28 Seimas prièmé Teologijos-filosofijos fakulteto pavadinimą. Matematikos-gamtos fakultete numatyta ịsteigti

${ }^{17}$ Lietuvos Respublikos Prezidento įsakymas Nr. 3, 192202 27. Lietuvos universiteto veikimo apyskaita, 192202 16-1924 06 15. Kaunas, 1925, p. 3.

181922 m. kovo 22 d., I sesijos 186 posèdis. Steigiamojo Seimo darbai. Kaunas, 1920-1922. 
Matematikos, Fizikos, Chemijos, Biologijos ir Agronomijos skyrius; Medicinos fakultete - Veterinarijos, Farmacijos ir Odontologijos; Technikos fakultete - Statybos, Mechanikos, Chemijos ir Elektrotechnikos skyrius. Kitų fakultetų pavadinimai, skyriai ir katedros nesukèlè Seime didesnių diskusijų.

Kovo $24 \mathrm{~d}$. Seimo posèdyje Universiteto statuto svarstymas vyko sklandžiai. Iš statuto buvo išbrauktas daug kairiųjų frakcijų priekaištų sulaukęs 26 paragrafas, kad Teologijos fakulteto profesoriai turi gauti episkopato sutikimą ${ }^{19}$. Daugiau diskusijų sukèlè klausimas, ar reikalingas viešas disertacijų gynimas, ar užteks tik parašyti disertaciją ir išlaikyti egzaminus. Vieni Seimo nariai tai laikė atgyvena, o V. Čepinskis tikino, kad viešas gynimas geriau ịrodo mokslininko erudiciją negu egzaminai ir disertacijos parašymas. Seimo dauguma nutarè, kad viešo disertacijos gynimo nereikia. Taip pat buvo nubalsuota, kad Universitetas ir atskiri fakultetai turi teisę igyti nekilnojamojo ir kilnojamojo turto.

Pirmajame Lietuvos universiteto statute buvo 56 paragrafai, suskirstyti i 8 skyrius: bendrieji dèsniai, fakultetai, mokslo personalas, fakultetų tarybos, Universiteto taryba, Universiteto klausytojai, diplomas ir mokslo laipsnis, turtas ir lèšos. Statutas suteikè Universitetui plačią autonomiją. Jame nebuvo nuostatų, kurios varžytų Universiteto veiklą, o nustatyti tik bendri veikimo principai, tačiau buvo numatytos konkrečios kiekvieno fakulteto katedros. Fakultetai galejo steigti naujus skyrius ir katedras, tačiau panaikinti ịrašytų statute neturèjo teisès. Teologijos-filosofijos fakultetą sudarè Teologijos, Filosofijos, Teisių ir Istorijos skyriai ${ }^{20}$, tačiau iš statute numatytų 4 skyrių fakultete išaugo tik 2 - Teologijos ir Filosofijos. Statute neliko Socialinių mokslų fakulteto, o vietoj jo turejjo būti įsteigti Teisių ir Humanitarinių mokslų fakultetai. Iš pradžių jie skyrių neturèjo. Universiteto statuto prièmimo

191922 m. kovo 24 d., I sesijos 187 posedis. Steigiamojo Seimo darbai. Kaunas, 1920-1922.

${ }^{20}$ Universiteto statutas. Vyriausybès žinios. 1922, balandžio 22 (Nr. 86), p. 1-2. 
analizè rado, kad Seimo frakcijų nuomonès daugiausia išsiskyrè dèl Teologijos-filosofijos fakulteto ịkūrimo, nevienodo autonomijos sąvokos supratimo ir net ịvairių katedrų steigimo. Dèl Seimo frakcijų nesutarimų Lietuvos universitetas buvo atidarytas remiantis $1918 \mathrm{~m}$. gruodžio 5 d. Lietuvos Tarybos išleistu ịstatymu ir Vilniaus universiteto statutu, tačiau galiausiai kompromisas Seime buvo pasiektas - Krikščionių demokratų blokas nusileido kairiosioms frakcijoms dèl Teologijos-filosofijos fakulteto pavadinimo ir dèstytojų skyrimo, o kairiosios partijos dèl Teologijos-filosofijos fakulteto steigimo.

\section{2. Švietimo klausimai Konstitucijoje}

Lietuvos Respublikos Konstitucijos projektą parengė 14 narių komisija: pirmininkas krikščionis demokratas Antanas Tumėnas, nariai - Krikščionių demokratų bloko atstovai Kazys Bizauskas, Zigmas Starkus, kunigas Justinas Staugaitis, kunigas Kazimieras Šaulys, Juozas Vailokaitis, Valstiečių liaudininkų bloko atstovai Kazys Grinius, Gabrielė Petkevičaitè, Mykolas Sleževičius ir Matas Untulis, Socialdemokratų - Vincas Čepinskis ir Kazys Venclauskis, Žydų frakcijos atstovas Maksas Soloveičikas ir Lenkų frakcijos narys Adolfas Grajevskis. Pastarasis mažai dalyvavo komisijos darbe, nes pasirašè $1921 \mathrm{~m}$. birželio 19 d. Tautų Sąjungai išsiųstą memorandumą dèl lenkų persekiojimo Lietuvoje ir po Seime $1921 \mathrm{~m}$. liepos $6 \mathrm{~d}$. kilusio incidento nedalyvavo jo darbe, tačiau Seimo nario mandatą išsaugojo ${ }^{21}$.

Svarstant Konstituciją kairiųjų frakcijų atstovai griežtai pasisakè prieš tai, kad ị Konstituciją būtų ịrašytas privalomas tikybos dèstymas. 1922 m. liepos 1 d. svarstant Konstitucijos projektą trečiuoju skaitymu socialdemokratas V. Čepinskis aiškino, kad tikybos dèstymas yra

${ }^{21}$ Stravinskienė, V.; Grajevskis, A. Lietuvos Steigiamojo Seimo (1920-1922 metu) nariu biografinis žodynas. Vilnius: Vilniaus pedagoginio universiteto leidykla, 2006, p. 155. 
švietimo programos dalykas, todèl jo įrašyti ị Konstituciją nereikia ${ }^{22}$. Jam pritarẻ liaudininkas M. Sleževičius, jis siūlè, kad tikyba būtų fakultatyvinis dalykas. Krikščionių demokratų bloko atstovai buvo priešingos nuomonès. Kunigas J. Staugaitis aiškino, kad jei šis klausimas rūpi 90 procentų Lietuvos piliečių, tai galima jị ịrašyti ị Konstituciją.

$1922 \mathrm{~m}$. liepos $21 \mathrm{~d}$. trečiuoju skaitymu buvo svarstomas Konstitucijos IX skyrius, skirtas švietimo reikalams ${ }^{23}$. Jame rašoma, kad mokyklas gali steigti valstybe், savivaldybès, visuomenès organizacijos ir atskiri asmenys, tačiau „visos mokyklos yra valstybès priežiūroje įstatymų nurodytose ribose ${ }^{\text {"24 }}$. Daugiausia ginčų sukèlè 89 paragrafas, ịteisinantis privalomą religijos mokymą. Socialdemokratai ir liaudininkai siūlè ịvesti fakultatyvinị tikybos mokymą, tačiau 42 balsais prieš 19 nubalsuota už privalomą religijos mokymą.

$1922 \mathrm{~m}$. liepos $26 \mathrm{~d}$. tęsiant svarstymą dauguma balsavo už paragrafą, kuriame užfiksuota, kad pradžios mokslas yra privalomas, o valstybès ir savivaldybès mokyklose - ir nemokamas ${ }^{25}$. Krikščionių demokratų lyderio Mykolo Krupavičiaus ir kunigu iniciatyva buvo itrauktas naujas paragrafas, kuriame įrašyta, kad privačios konfesinès mokyklos, jei jos tenkina valstybinių mokyklų programų minimumą, gauna valstybès iždo paramą, atitinkančią mokinių ir piliečių, priklausančių tai tikybos organizacijai, skaičių. Taip pat buvo pateikta panaši kunigo A. Šmulkščio parengta redakcija. Pasiūlymas sulaukè liaudininkų V. Lašo, A. Tamošaičio, socialdemokratų K. Venclauskio ir V. Čepinskio, nepartinio Jurgio Žitinevičiaus ir kt. kritikos. Kairieji teigè, kad straipsniu norima padidinti religinių mokyklų skaičių ir kartu

${ }^{22} 1922$ m. liepos 1 d., I sesijos 218 posėdis. Steigiamojo Seimo darbai. Kaunas, 1920-1922.

231922 m. liepos 21 d., I sesijos 228 posėdis. Steigiamojo Seimo darbai. Kaunas, 1920-1922.

${ }^{24}$ Laučka, B. J. Keletas žvilgsnių ị Lietuvos 1922 metų konstituciją: jos kilmè ir pagrindiniai principai. Aidai. 1985, Nr. 3, p. 133-147.

251922 m. liepos 26 d., I sesijos 230 posėdis. Steigiamojo Seimo darbai. Kaunas, 1920-1922. 
išnaudoti valstybę. V. Čepinskio nuomone, šis straipsnis yra pavojingas „valstybès nepriklausomam egzistavimui“, nes tokios mokyklos ugdys žmones, nemokančius savarankiškai mąstyti. Už pasiūlymą pasisakè kunigai Jonas Steponavičius ir M. Krupavičius. Šis paragrafas, pasak M. Krupavičiaus, buvo siūlomas siekiant apginti daugumos piliečių katalikų teises. Gale posèdžio liaudininkai pareiškè, kad negali balsuoti už ši pasiūlymą ir paliko posèdžio salę. Už ši paragrafą buvo balsuojama 1922 m. liepos 27 d. 231-ame Seimo posėdyje ${ }^{26}$. Jo pradžioje buvo užsiregistravęs 91 Seimo narys, tačiau po pertraukos, kai reikèjo balsuoti už 90 paragrafą, salejje buvo tik 58 nariai. Seimo Pirmininkas A. Stulginskis pranešè, kad M. Krupavičius savo pataisą atsièmė. Dauguma balsavo už A. Šmulkščio redaguoto paragrafo prièmimą.

1922 m. rugpjūčio $1 \mathrm{~d}$. Steigiamajame Seime buvo priimta Lietuvos Respublikos Konstitucija. Už Konstituciją balsavo 59 Seimo nariai Krikščionių demokratų blokas, Žydų frakcija ir nepartinis J. Žitinevičius. Prieš balsavo nepartinis Kazys Zubauskas, o Valstiečių liaudininkų blokas ir Socialdemokratų frakcija balsavime nedalyvavo ${ }^{27}$. Po balsavimo Seimui giedant himną, Socialdemokratų frakcija išejo iš posèdžių salès. Prieš balsavimą M. Sleževičius pasakè, kad Valstiečių liaudininkų blokas negali balsuoti už Konstituciją, kadangi ji itteisina dideles galias turinčią Prezidento instituciją, nepanaikina cenzūros ir įveda priverstinị tikybos mokymą, todèl visą atsakomybę už ją turi prisiimti Krikščionių demokratų blokas. Socialdemokratų frakcijos nuostatas dèl Konstitucijos išdèstė Steponas Kairys, Vladas Požèla ir K. Venclauskis, jie teigè, kad frakcija nedalyvaus balsavime dèl Konstitucijos, nes joje Prezidentas turi daugiau galių negu kitose valstybèse karalius, Bažnyčia neatskirta nuo valstybės, o mokykla nuo Bažnyčios, tautinėms mažumoms nesuteikiama teisè kalbėti sava kalba viešajame

${ }^{26} 1922$ m. liepos 27 d., I sesijos 231 posėdis. Steigiamojo Seimo darbai. Kaunas, 1920-1922.

271922 m. rugpjūčio 1 d., I sesijos 234 posėdis. Steigiamojo Seimo darbai. Kaunas, 1920-1922. 
ir valstybės gyvenime, darbininkams nesuteikiama teisè streikuoti, įteisinama reguliari kariuomenè, nors socialdemokratai siūlè apginkluoti visus piliečius, o Konstitucija įtvirtina krikščionių demokratų valdymą.

Galima pritarti istorikui D. Mačiuliui, kuris rašè, kad 1922 m. Lietuvos Konstitucija įteisino privilegijuotą konfesinių mokyklų padetị, palyginti su kitomis mokyklomis. Tai padaryta konstituciškai įtvirtinant privačių konfesinių mokyklų, tenkinančių įstatymiškai numatytą mokymo programos minimumą, teisę iš valstybės iždo švietimo reikalams gauti tokią biudžeto dalį, „kuri atitinka oficialiai priklausančių tai tikybinei organizacijai, kurios mokslu tos mokyklos vedamos, Lietuvos piliečių ir mokinių skaičiui “28.

Steigiamajame Seime daugumą sudariusiems krikščionims demokratams buvo svarbu, kad jaunimas būtų ugdomas katalikiška dvasia, todèl Konstitucijoje jie įtvirtino privalomą tikybos mokymą. Kairiosios partijos atkakliai gynė savo ideologines nuostatas, norèdamos atskirti valstybę nuo Bažnyčios ir Bažnyčią nuo mokyklos, nors jų idejjoms nepritarè dauguma Lietuvos piliečių. Siekdami, kad nebūtų priimami jų ideologijai priešingi ịstatymai, kairieji Seimo posèdžiuose elgèsi destruktyviai: nesilaike reglamento, per balsavimus išeidavo iš posėdžių salès, tačiau krikščionims demokratams pakakdavo savo bloko atstovų balsų.

\section{Pradžios mokyklų įstatymo svarstymas ir prièmimas}

1919 m. Lietuvoje veikè 1036 pradžios mokyklos ${ }^{29}$. Pradžios mokyklų i̇statymas Steigiamajame Seime pradètas svarstyti $1921 \mathrm{~m}$.

${ }^{28}$ Mačiulis, D. Kultūrinès autonomijos idèja ir katalikiško švietimo sistema tarpukario Lietuvoje (1918-1940 m.). Lietuviu kataliku mokslo akademijos metraštis. Vilnius, 2011, t. 35 , p. 81 .

${ }^{29}$ Vokietaitis, J. Pradžios mokslo plitimo 10 metų (1918-1928) apžvalga. Pirmasis Nepriklausomos Lietuvos dešimtmetis, 1918-1928. Kaunas: Śviesa, 1990, p. 314. 
balandžio 5 d. posėdyje. Referuodamas ši ịstatymo projektą K. Jokantas pripažino, kad komisijoje kilo daug ginčų dèl pradžios mokyklų santykio su valstybe, dėstomųjų dalykų, ypač dèl tikybos dėstymo, valsčių švietimo komisijų ir baigiamųjų egzaminų ${ }^{30}$. Vis dèlto komisija nutarè, kad tikyba turi būti privaloma, tačiau, jei tèvai parašys prašymą, kad jų vaikai nebūtų mokomi tikybos, mokiniai nuo šių pamokų bus atleisti.

Švietimo ministras K. Bizauskas paaiškino, kad Švietimo ministerija sutinka su komisijos pataisomis, nes pradžios mokyklos veikia jau treji metai, tačiau jų veikla nèra reglamentuota ịstatymo, todèl kartais kyla nesusipratimų su savivaldybemis, kurios, pavyzdžiui, atsisako aprūpinti jų teritorijoje esančias pradžios mokyklas kuru, nes nèra tokio îstatymo. Vis dẻlto švietimo ministras pasisakė už tai, kad privačiose mokyklose būtų mokama už mokslą, nes ne visos visuomeninès organizacijos ar privatūs asmenys turi pakankamai lèšų joms išlaikyti.

Socialistų liaudininkų ir Valstiečių sajungos frakcijų atstovas K. Kupčiūnas, socialdemokratų atstovas V. Čepinskis buvo griežtai nusistatę prieš tikybos dèstymą pradžios mokyklose, vadino tai grị̌imu i viduramžius ir reikalavo atskirti tikybą nuo mokyklos. Krikščionių demokratų bloko atstovas kunigas Jonas Stankevičius pareiškè, kad neverta ginčytis dèl atskirų dalykų dèstymo, nes, jo manymu, svarbiausia, kad mokyklų programos būtų sudarytos taip, kad jose būtų pabrèžiama valstybės idèja. Lenkų frakcijos atstovo Bronislovo Liauso aiškinimu, nedemokratiška, kad steigiant privačias mokyklas reikia Švietimo ministerijos leidimo.

Diskusijos dèl Pradžios mokyklų ịstatymo projekto buvo tęsiamos $1921 \mathrm{~m}$. balandžio 8 d. Seimo posėdyje. Krikščionių demokratų atstovas J. Staugaitis, kalbėdamas savo vardu, aiškino, kad jeigu tėvai reikalauja, mokykloje turi būti dèstoma tikyba, taip pat jis pasisakè už

${ }_{30} 1921$ m. balandžio 5 d., I sesijos 77 posèdis. Steigiamojo Seimo darbai. Kaunas, 1920-1922. 
valstybės pagalbą privačioms mokykloms ${ }^{31}$. Jo partijos narys Vytautas Bičiūnas tvirtino, kad norėdami pašalinti tikybą iš mokyklų kairieji siekia paskleisti savo socialistines pažiūras. Jo teigimu, lietuvių tauta yra katalikiška tauta, ir „netikybinès mokyklos“ steigimas būtų nusižengimas lietuvių tautai, nes niekas nežino, kur nuves socializmas. V. Bičiūnas pritare tikybos dèstymui mokyklose ir oponuodamas kairiesiems sakè, kad jie, išmesdami tikybą iš mokyklos, nori prievarta ịvesti kitą tikejjimą, tačiau, jo nuomone, tauta priešinsis ir neleis to padaryti. Nepartinis J. Žitinevičius siūlè tikybos mokymą padaryti pasirenkamuoju dalyku. Privalomą tikybos dèstymą rèmẻ krikščionys demokratai Stasys Tijūnaitis ir Kazys Ambrozaitis, taip pat Lenkų frakcijos atstovas B. Liausas.

Balandžio $12 \mathrm{~d}$. diskusijose dèl ịstatymo projekto vèl pagrindinę vietą užèmė tikybos dèstymas ${ }^{32}$. Prieš tikybos dèstymą vèl kalbejjo socialdemokratas V. Čepinskis, jam oponavo krikščionys demokratai Antanas Simanauskas, J. Staugaitis, A. Šmulkštys. Dauguma Seimo narių Z. Starkaus siūlymu nubalsavo už tai, kad ịstatymo projekto pagrindu būtų imamas Ministrų kabineto parengtas projektas. Antruoju skaitymu įstatymas buvo priimtas $1921 \mathrm{~m}$. spalio 4 dieną. Pusantrų metu projektas buvo svarstomas komisijose ir tik $1922 \mathrm{~m}$. spalio $6 \mathrm{~d}$. paskutiniame 257-ame posėdyje Steigiamasis Seimas prièmé Pradžios mokyklų ịstatymą.

Kairiosios frakcijos prieštaravo įstatymo prièmimui. Socialdemokratas V. Čepinskis siūlè atidèti ịstatymo svarstymą, nes Seimo nariai nespèjo ị ji îsigilinti. Liaudininkas A. Tamošaitis kritikavo, kad ịstatyme įtvirtinta neribota tèvų komiteto valdžia suteikia dvasininkams teisę kontroliuoti mokytojus, socialdemokratas Jeronimas Plečkaitis aiškino, kad įstatymas nepriimtinas Socialdemokratų frakcijai, nes

311921 m. balandžio 8 d., I sesijos 78 posėdis. Steigiamojo Seimo darbai. Kaunas, 1920-1922.

321921 m. balandžio 12 d., I sesijos 79 posèdis. Steigiamojo Seimo darbai. Kaunas, 1920-1922. 
leidžia Bažnyčiai kištis ị mokyklos reikalus ${ }^{33}$. Pradejjus svarstyti 9 paragrafą, kuris įteisino privalomą tikybos mokymą, vèl kilo didžiulis kairiųjų frakcijų pasipriešinimas. Liaudininkas K. Kupčiūnas aiškino, kad straipsnis yra antikonstitucinis, ir kaltino Krikščionių demokratų bloką, jog jie mokyklas nori paversti savo agitacijos įrankiu. Liaudininkai M. Sleževičius ir V. Lašas tvirtino, kad šio įstatymo negalima svarstyti, nes Bendrosios teisès komisijos pataisos pateiktos tik prieš posèdi, o ne kaip reikalauja statutas - prieš 48 valandas. Jiems pritarè socialdemokratas Kipras Bielinis.

Steigiamojo Seimo Pirmininkas A. Stulginskis paaiškino, kad pagal nusistovėjusią praktiką tik Seimo nariai, norintys pateikti įstatymo pataisas, turi jas pateikti prezidiumui likus 48 valandoms iki svarstymo, o kitiems Seimo nariams užtenka gauti pataisas prieš posėdị. Kairiųjų frakcijai pakèlus didelị triukšmą, Steigiamojo Seimo Pirmininkas turejjo paskelbti pertrauką, kad nurimtų aistros. Po pertraukos Seimo Pirmininkas A. Stulginskis, turbūt pasitaręs su Krikščionių demokratų bloko atstovais teisininkais, vis dèlto sutiko, kad Bendrosios teisès komisijos pastabos parašytos per vèlai, ir pasiūlè plenumui balsuoti, ar grąžinti projektą komisijai. Daugumai nubalsavus, kad projekto grąžinti nereikia, Seimo Pirmininkas pareiškè, kad naujos Bendrosios teisès komisijos pataisos nebus teikiamos balsavimui. Tai buvo kairiosioms frakcijoms netikètas ejjimas, nes kai kurioms naujoms pataisoms jos vis dèlto pritarè. M. Sleževičius ir A. Tamošaitis vèl apkaltino A. Stulginskị Seimo statuto laužymu. Kilus triukšmui, Seimo Pirmininkas turejjo nutraukti posèdị ir skelbti pertrauką.

Tęsiant svarstymą vèl aktyviausi kalbėtojai buvo liaudininkai A. Tamošaitis ir K. Kupčiūnas, jie kalbejjo svarstant kiekvieną paragrafą. A. Tamošaitis aiškino, kad nereikia baigiamųjų egzaminų, kad negalima skirti mokytojų, neturinčių mokslo cenzo. K. Kupčiūno teigimu, mokytojai buvo persekiojami dèl savo pažiūrų. Apsvarsčius visus

${ }_{33} 1922$ m. spalio 6 d., I sesijos 257 posedis. Steigiamojo Seimo darbai. Kaunas, 1920-1922. 
paragrafus, kai reikèjo balsuoti už visą ịstatymą, liaudininkų lyderis M. Sleževičius pasakè: kadangi įstatymas svarstomas negirdètu būdu, Seimo daugumai nepanorẻjus svarstyti komisijų pataisų, krikščionims demokratams norint užsitikrinti galimybę paversti mokyklas savo politikos įrankiu, Valstiečių liaudininkų blokas pareiškia, kad tokio ịstatymo svarstyme jie negali dalyvauti, ir išeina iš salès. K. Ambrozaitis paaiškino, kad šis ịstatymas buvo vilkinamas dèl socialistų obstrukcijos ir pagaliau priejo prie galutinès stadijos, todèl krikščionys demokratai balsuos už ši îstatymą. Seimo Pirmininkas paskelbẻ balsavimą, pasirodè, kad prieš įstatymą nebalsavo niekas.

Istatyme patvirtinta visiems mokyklinio amžiaus vaikams privaloma ketverių metų pradžios mokykla. Numatyta, kad pradžios mokykla steigiama ne mažesniam kaip 500 gyventojų skaičiui. Vienam mokytojui skiriama nuo 32 iki 60 mokinių. Pradžios mokyklą privalo lankyti visi 7-14 metų vaikai. Tikybos dèstymas privalomas, Švietimo ministerijos ir savivaldybių mokyklose mokslas yra nemokamas. Pradžios mokyklų mokytojų vaikams suteikiama teisė nemokamai mokytis visose aukštesniosiose valstybinèse ar savivaldybių mokyklose.

\section{Išvados}

1. Svarbiausi Steigiamojo Seimo darbai švietimo srityje buvo Lietuvos universiteto statutas, Pradžios mokyklų ịstatymas ir Konstitucijoje švietimo reikalams skirtas IX skyrius, kuris įteisino privalomą pradžios mokslą.

2. Istatymuose, susijusiuose su švietimu, didžiausios Steigiamojo Seimo frakcijos stengèsi ittvirtinti savo ideologines nuostatas, tačiau tai pavyko padaryti absoliučią balsų daugumą turèjusiam Krikščionių demokratų blokui, kurio nuostatos atitiko daugumos Lietuvos piliečių siekius.

3. Kairiosios Seimo frakcijos, siekusios Bažnyčios atskyrimo nuo valstybès ir mokyklos atskyrimo nuo Bažnyčios, nepaisydamos to, kad 
jų idèjoms nepritaria dauguma Lietuvos piliečiu, atkakliai bandè įtvirtinti jas įstatymuose ir Konstitucijoje, o nepasisekus visaip trukde Seimo darbą, todèl šie svarbūs ịstatymai buvo priimti pavèluotai.

\title{
THE WORK OF THE CONSTITUENT SEIMAS IN THE FIELD OF EDUCATION: EXPECTATIONS AND PROBLEMS
}

\author{
Audroné VeilentienĖ
}

\section{Summary}

Keywords: Seimas; fraction; university; Statute; school; education; draft law.

The article deals with the activities of the Constituent Seimas in the area of education. The main laws on education adopted by the Seimas were the Statute of the University of Lithuania and the Law on Primary Schools. In addition, obligatory primary education and obligatory teaching of religion were introduced in the Lithuanian Constitution. The article also reveals some ideological viewpoints of the Seimas' fractions and of some individual members of the Seimas on education. The ruling block of Christian Democrats, having the approval of the majority of Lithuanian people, sought to establish their ideological viewpoints, however, hostile attitude of Peasants and Populist block and Social Democrats towards religion blocked the ideas of Christian Democrats and going to trade-offs. The greatest controversy was caused due to the establishment of Theology Faculty in the University of Lithuania and obligatory teaching of religion in primary schools. Some Lithuanian political parties failed to understand the expectations of believers who represented about $90 \%$ of Lithuania's population.

Iteikta 2017 m. spalio $4 d$. 